\title{
Do centennial tree-ring and stable isotope trends of Larix gmelinii (Rupr.) Rupr. indicate increasing water shortage in the Siberian north?
}

\author{
Olga Vladimirovna Sidorova - Rolf T. W. Siegwolf • Matthias Saurer · \\ Alexander V. Shashkin · Anastasia A. Knorre - Anatoliy S. Prokushkin · \\ Eugene A. Vaganov $\cdot$ Alexander V. Kirdyanov
}

Received: 3 July 2008/ Accepted: 22 June 2009/Published online: 10 July 2009

(C) Springer-Verlag 2009

\begin{abstract}
Tree-ring width of Larix gmelinii (Rupr.) Rupr., ratios of stable isotopes of $\mathrm{C}\left(\delta^{13} \mathrm{C}\right)$ and $\mathrm{O}\left(\delta^{18} \mathrm{O}\right)$ of whole wood and cellulose chronologies were obtained for the northern part of central Siberia (Tura, Russia) for the period 1864-2006. A strong decrease in the isotope ratios of $\mathrm{O}$ and $\mathrm{C}$ (after atmospheric $\delta^{13} \mathrm{C}$ corrections) and treering width was observed for the period 1967-2005, while weather station data show a decrease in July precipitation, along with increasing July air temperature and vapor pressure deficit (VPD). Temperature at the end of May and the whole month of June mainly determines tree radial growth and marks the beginning of the vegetation period in this region. A positive correlation between tree-ring width and July precipitation was found for the calibration period 1929-2005. Positive significant correlations between C isotope chronologies and temperatures of June and July were found for whole wood and cellulose and negative relationships with July precipitation. These relationships are strengthened when the likely physiological response of trees to increased $\mathrm{CO}_{2}$ is taken into account (by applying a recently developed $\delta^{13} \mathrm{C}$ correction). For the $\mathrm{O}$ isotope ratios, positive relationships with annual temperature, VPD
\end{abstract}

Communicated by Dan Yakir.

O. V. Sidorova $(\bowtie)$ · A. V. Shashkin · A. A. Knorre

A. S. Prokushkin · E. A. Vaganov · A. V. Kirdyanov

V.N. Sukachev Institute of Forest,

660036 Akademgorodok, Russia

e-mail: ovsidorova@forest.akadem.ru; olga.sidorova@psi.ch

O. V. Sidorova · R. T. W. Siegwolf · M. Saurer

Paul Scherrer Institute, 5232 Villigen, Switzerland

A. A. Knorre · E. A. Vaganov

Siberian Federal University,

Svobodny 79, 660041 Krasnoyarsk, Russia of July and a negative correlation with annual precipitation were observed. The $\delta^{18} \mathrm{O}$ in tree rings may reflect annual rather than summer temperatures, due to the late melting of the winter snow and its contribution to the tree water supply in summer. We observed a clear change in the isotope and climate trends after the 1960s, resulting in a drastic change in the relationship between $\mathrm{C}$ and $\mathrm{O}$ isotope ratios from a negative to a positive correlation. According to isotope fractionation models, this indicates reduced stomatal conductance at a relatively constant photosynthetic rate, as a response of trees to water deficit for the last half century in this permafrost region.

Keywords Stable carbon isotope ratio .

Stable oxygen isotope ratio - Climatic changes .

Tree-ring width · Tura

\section{Introduction}

Studies of Siberian forests are important, because these sensitive ecosystems are very responsive to climate changes (Myneni et al. 1997; Vaganov and Shiyatov 1998; Briffa 2000; Sidorova et al. 2008). Recent reports about the impact of the rapidly increasing atmospheric $\mathrm{CO}_{2}$ concentrations suggest that northern forest ecosystems may be particularly strongly affected by global warming (Keeling et al. 1996; Vaganov and Shiyatov 1998; Serreze et al. 2000). Increased C storage in phytomass (Körner 2000; Knorre et al. 2006; IPCC 2001, 2007), changes in plant distribution and ecosystem biogeochemical cycles and degradation of permafrost (Osterkamp and Romanovsky 1999; IPCC 2001, 2007; Sugimoto et al. 2002; Delisle 2007) are among the predicted likely future consequences. Moreover, climate change and increasing $\mathrm{CO}_{2}$ may have a combined effect on tree growth 
that does not always result in higher $\mathrm{C}$ accumulation for high-latitude northern forests. A number of studies report decreasing radial tree growth of white spruce (Picea glauca) caused by drought stress associated with increasing temperature at the northern tree line in Alaska during the last century (Barber et al. 2000; D'Arrigo et al. 2004; Wilmking and Juday 2005). However, the opposite pattern showing increasing radial growth was observed for more temperate regions, for instance the Swiss Central Plateau (Saurer et al. 1997a), the White Mountains (Sierra Nevada, US) (Graumlich 1991) and north-eastern France (Duquensnay et al. 1998).

Tree growth is influenced by many factors such as solar irradiance, temperature, precipitation, air humidity, soil and ground water, nutrient availability as well as water from melting permafrost (Schweingruber et al. 1996; Vaganov et al. 1999; McCarrol and Loader 2004). Treering width and tree-ring isotope composition [ratios of stable isotopes of $\mathrm{C}\left(\delta^{13} \mathrm{C}\right)$ and $\left.\mathrm{O}\left(\delta^{18} \mathrm{O}\right)\right]$ are indicators for both temperature and moisture regime changes, where fractionation processes during $\mathrm{CO}_{2}$ uptake are important for $\delta^{13} \mathrm{C}$, while for $\delta^{18} \mathrm{O}$ changes in the soil and leaf water isotope ratio are determining factors (Treydte et al. 2001; McCarroll and Loader 2004; Saurer and Siegwolf 2007; Leavitt et al. 2008).

The $\mathrm{C}$ isotopic ratio in tree rings reflects signals of water availability and air humidity as a result of the impact of climate on photosynthesis. During photosynthesis several fractionation steps take place, first when $\mathrm{CO}_{2}$ from the atmosphere diffuses into the intercellular spaces, and second during $\mathrm{CO}_{2}$ fixation by the enzyme Rubisco. The opening and closure of stomata determines the water control. Under dry conditions the stomata close to conserve water, while under wet conditions the stomata open up to optimize $\mathrm{CO}_{2}$ assimilation. Changes in the assimilation rate of the needles will therefore influence the intercellular $\mathrm{CO}_{2}$ concentration $\left(c_{\mathrm{i}}\right)$ through changes of the rate at which the $\mathrm{CO}_{2}$ is utilized to form sugars and an increase or decrease in stomatal conductance will affect the rate at which this internal $\mathrm{CO}_{2}\left(c_{\mathrm{i}}\right)$ can be replenished (Farquhar et al. 1989). Plants discriminate more strongly against ${ }^{13} \mathrm{C}$ under conditions of high $c_{\mathrm{i}}$, when stomata are relatively wide open or photosynthesis is low. As trees respond to limited water resources, particularly under low amounts of precipitation and relatively warm and dry conditions by reducing the stomatal conductance and photosynthetic rate, these result in a diminished $c_{\mathrm{i}}$ (Scheidegger et al. 2000; Saurer and Siegwolf 2007).

$\mathrm{O}$ isotopes in tree rings contain isotope signals related to temperature and precipitation, which represent the source water for trees (Craig 1961; Dansgaard 1964; Saurer and Siegwolf 2007). Water moves from the soil (ground water, soil, snow melt water) via xylem to the leaves/needles, where the lighter isotopes $\left({ }^{16} \mathrm{O}\right)$ evaporate more easily than heavier ${ }^{18} \mathrm{O}$, resulting in enriched leave/needle water (Farquhar and Lloyd 1993; Scheidegger et al. 2000; Cernusak et al. 2003). Enrichment in $\delta^{18} \mathrm{O}$ may be enhanced under drought conditions (Yakir and Sternberg 2000). Barbour et al. (2001) showed that $\delta^{18} \mathrm{O}$ is mostly negatively correlated with stomatal conductance, because changes in transpiration influence the leaf water enrichment by the replenishment of leaf water with unenriched soil water. A mixed $\delta^{18} \mathrm{O}$ signal of source and leave/needle water enrichment is stored in the wood and cellulose of the tree rings (Saurer et al. 1997b; Roden and Ehleringer 2000). During the biochemical transformations from $\mathrm{CO}_{2}$ to wood, the $\mathrm{O}$ isotope signal undergoes the following major modifications: (1) it shifts by approximately $28 \%$ during the formation of cellulose (Stenberg et al. 1986); (2) the signal amplitude is smoothed (damping effect) (Saurer et al. 1997b) by the exchange of $\delta^{18} \mathrm{O}$ of source and xylem water during cellulose synthesis (Roden and Ehleringer 2000). Accordingly the $O$ isotope ratio signals reveal environmental information as a response to changes in temperature, $\mathrm{CO}_{2}$ and humidity. As stomatal conductance decreases with increasing ambient $\mathrm{CO}_{2}$ concentration the water vapor exchange between the leaf and the ambient air is reduced leaving its fingerprint as outlined above (Drake et al. 1997; Saurer and Siegwolf 2007).

The information on evaporative enrichment contained in the $\delta^{18} \mathrm{O}$ of organic matter is useful to distinguish whether a change in the $c_{\mathrm{i}}$, calculated using $\delta^{13} \mathrm{C}$, is due to changes in stomatal conductance or photosynthetic rate (Scheidegger et al. 2000). C and $\mathrm{O}$ isotopes measured in the same tree rings may, therefore, be a useful tool for better understanding the response of trees to both climate and changes in $\mathrm{CO}_{2}$. Since trees assimilate atmospheric $\mathrm{CO}_{2}$, changes in the atmospheric isotope composition will be reflected in the tree-ring $\mathrm{C}$ isotope ratio. However, the concentration of $\mathrm{CO}_{2}$ can also influence photosynthesis and therefore the isotope discrimination. Tree-ring $\delta^{13} \mathrm{C}$ chronologies showing a decline over recent decades, that is not explained by a parallel change in the controlling climatic variables, have been reported from several areas, including the Swiss Alps (Saurer et al. 1997b; Treydte et al. 2001), north-eastern France (Duquensnay et al. 1998) and Finland (Gagen et al. 2007). McCarroll et al. (2009) suggest that this is a threshold effect, with trees having reached the limits of physiological adaptation to increasing $\mathrm{CO}_{2}$ levels in the atmosphere. A study of both tree-ring width and isotope data may therefore help to disentangle the effects of climate and $\mathrm{CO}_{2}$ on the trees.

Studies of the isotopic composition of tree rings in the northern regions of Eurasia have been primarily conducted for $\mathrm{C}\left(\delta^{13} \mathrm{C}\right)$ (Kagawa et al. 2003; Gagen et al. 2007; Kirdyanov et al. 2008; Sidorova et al. 2008) and rarely for 
O $\delta^{18} \mathrm{O}$ (Saurer et al. 2002; Sidorova et al. 2008), but using both isotopes could be very helpful in improving our understanding of the forest response to environmental changes of the past century.

In this paper we addressed the following questions:

1. Do Siberian larch [Larix gmelinii (Rupr.) Rupr.] trees, which represent one of the main species in highlatitude northern forests, show trends in tree-ring width and stable isotope compositions for the recent period?

2. Which climatic factor (temperature/precipitation) determines radial growth of larch trees growing on permafrost during the recent climatic changes under increasing $\mathrm{CO}_{2}$ ?

3. What kind of climatic signals can be extracted from stable isotope data with and without applying detrending procedures?

To answer these questions we present a combined study of tree-ring width and stable isotopic ratios $\left(\delta^{13} \mathrm{C}, \delta^{18} \mathrm{O}\right)$ for whole wood and cellulose from larch trees growing on permafrost in the northern part of central Siberia (Russia) for the period 1864-2006.

\section{Materials and methods}

\section{Studied region and site description}

The study was conducted $30 \mathrm{~km}$ north of the settlement of Tura $\left(64^{\circ} 32^{\prime} \mathrm{N}-100^{\circ} 14^{\prime} \mathrm{E}, 204 \mathrm{~m}\right.$ a.s.l.) within the region of continuous permafrost in the northern part of central Siberia (Fig. 1). According to the Tura weather station $\left(64^{\circ} 27^{\prime} \mathrm{N}, 100^{\circ} 23^{\prime} \mathrm{E}, 168 \mathrm{~m}\right.$ a.s.l.) the mean annual temperature for the period $1928-2006$ is $-9.1^{\circ} \mathrm{C}$. The growing season length is approximately 70 days and lasts from the end of May to the beginning of September (Abaimov et al.

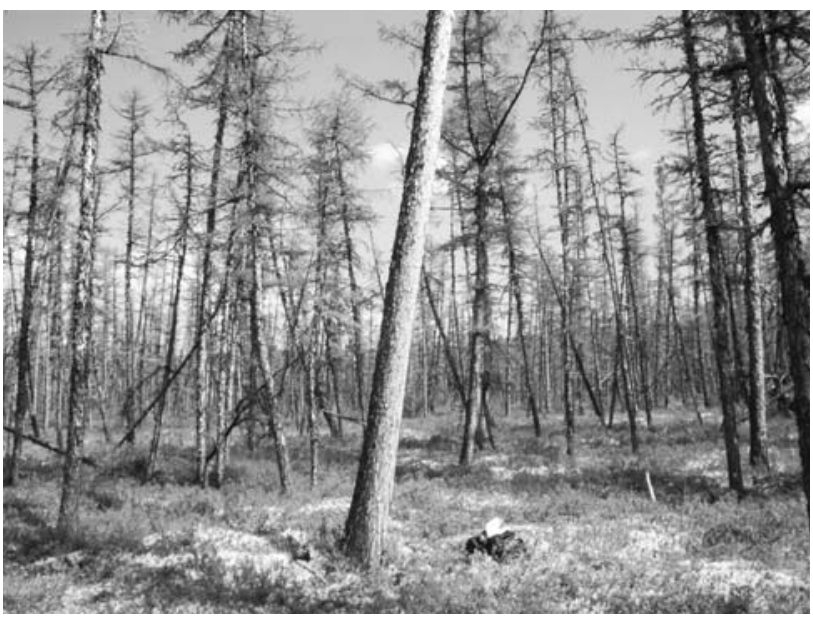

Fig. 1 Photograph of the study site (photograph: A. V. Kirdyanov)
1997). Mean monthly temperatures vary between $+16.6^{\circ} \mathrm{C}$ in July (the warmest month) and $-36.2^{\circ} \mathrm{C}$ in January (the coldest month). Temperature extremes can range between $+36^{\circ} \mathrm{C}$ in summer and drop below $-55^{\circ} \mathrm{C}$ in winter time. The annual amount of precipitation is $368 \mathrm{~mm}$ (19362006) with about $60 \%$ falling as a rain (June-September).

Samples of larch trees [Larix gmelinii (Rupr.) Rupr.] were collected in pristine open canopy larch stands (canopy closure is ca. 0.3 ) characterized by uneven-age structure with some 300-year-old individuals (Fig. 1). The stands in this region are common on flat terrains developed on deep fluvial deposits (second and third river terraces). The soil developed in such conditions is a Typic Haploturbel (USDA 1998). The organic soil layer represents an acidic mor-type forest floor of 10-20 cm thickness. The depth of mineral soil is $>1.5 \mathrm{~m}$ according to the soil survey conducted in adjacent burned areas, and the soil texture is silty loam. The depth of the active soil layer, defined as the part of the upper soil that thaws in summer, reaches a maximum in September up to $0.2-0.9 \mathrm{~m}$ depending on the microtopography (mounds and troughs) induced by cryoturbation. The rooting depth in troughs is limited by the organic layer when the upper mineral soil is over moistened (>90\%) and cold (maximum temperature is $1^{\circ} \mathrm{C}$ ). Rooting depths in mounds reach up to $40 \mathrm{~cm}$ with $80 \%$ of roots inhabiting the organic layer and upper $10 \mathrm{~cm}$ of mineral soil, which dry out in July (ca. 20\%). In general, the mature trees in the region have a superficial rooting system with lateral roots (which provide water and nutrients for the mature trees under study) mainly expanded into the warmer mounds and rarely into the colder (and sometimes "frozen") trough (Kajimoto et al. 2003).

Spatial mosaics of moist troughs and dry mounds in the studied terrains result in the lengthened fire intervals [140 years vs. 60-80 years as an average for the region (Kharuk et al. 2008)] and a higher survival of larch trees after a fire leading to the co-occurrence of different generations of larches within the stand.

The ground vegetation is dominated by dwarf shrubs (Ledum palustre L., Vaccinium vitis-idaea L.), mosses [Pleurozium schreberi (Brid.) Mit., Aulocomnium palustre (Hedw.) Schwaegr.] and lichens (Cladina spp. and Cetraria spp.).

Wood material and data treatment

Tree-ring cores were collected from 20 trees at a height of $1.3 \mathrm{~m}$ with a 0.5 -cm-diameter increment borer. The tree cores were measured using semi-automatic devices (LINTAB V-3.0; Germany) with a precision of $0.01 \mathrm{~mm}$ and cross-dated for determining the exact calendar date for each tree ring. The individual tree-ring width series were standardized using a negative exponential curve or 
regression line to remove age-related trends. The absolutely dated standardized site chronology was constructed using individual tree series within the 180- to 200-year age class (Cook and Kairiukstis 1990; Schweingruber 1996; Rinn 1996; Cook and Krusic 2008). The expressed population signal (EPS) was calculated to define a threshold level of common signal between tree-ring series in year-toyear variations, i.e., the sensitivity of the tree-ring width variabilities to changes of external factors, and is based on the average correlation between the trees. Normally, an EPS higher than 0.85 is considered as sufficient for climate reconstruction (Wigley et al. 1984; Cook and Kairiukstis 1990). The running correlations were calculated for overlapping 20-year periods, while moving with an advance of 1 year through the whole calibration period. The correlation coefficients are plotted as a function of the middle year of each period.

For the isotope analyses, eight tree cores from eight different trees from the same sample set were used. We selected cores with tree rings wide enough for isotope measurements and the highest correlation of individual tree-ring width series with the site chronology. To exclude the influence of the juvenile effect (McCarroll and Loader 2004; Gagen et al. 2008; Sidorova et al. 2008), we analyzed only tree rings with a cambial age greater than 40 years and at least 180 years, i.e., the isotope chronologies were constructed for the period after 1860 . The $\delta^{13} \mathrm{C}$ and $\delta^{18} \mathrm{O}$ were analyzed for pooled material (milling each single annual tree ring from eight trees together) for both whole wood and for cellulose. The two materials have been shown to yield partly independent signals (Borella et al. 1998; Sidorova et al. 2008). Material of each annual ring was milled to a fine powder and weighed into tin capsules for the analysis $\left(0.6-0.8 \mathrm{mg}\right.$ for ${ }^{13} \mathrm{C} /{ }^{12} \mathrm{C}$ and $1.1-1.3 \mathrm{mg}$ for ${ }^{18} \mathrm{O} /{ }^{16} \mathrm{O}$ ). The pooling procedure yields a reliable isotope chronology with a reduced number of samples (Treydte et al. 2001). Although pooling prevents the calculation of the common signal strength in the isotope chronologies (McCarroll and Loader 2004), other studies on conifers have obtained very strong common signals with as few as five trees (McCarroll and Pawellek 2001; Gagen et al. 2004, 2006), so the samples of eight as used here are likely to be more than adequate. For $\alpha$-cellulose extraction, a subsample of the whole wood was enclosed in filter bags and washed twice for $2 \mathrm{~h}$ in $5 \% \mathrm{NaOH}$ to remove the remaining lipids, resins and hemicellulose. A $7 \% \mathrm{NaClO}_{2}$ treatment was then performed for $36 \mathrm{~h}$ to remove the lignin (Loader et al. 1997). The packets were dried for $24 \mathrm{~h}$ at $50^{\circ} \mathrm{C}$.

The isotope ratios $\left(\delta^{13} \mathrm{C}\right.$ and $\left.\delta^{18} \mathrm{O}\right)$ were determined on whole wood and cellulose using a Delta-S isotope ratio mass spectrometer (Finnigan MAT, Bremen, Germany) linked to two elemental analyzers (EA-1108, and EA-1110; Carlo Erba, Italy) via a variable open split interface
(ConFlo-II; Finnigan MAT, Bremen, Germany) at the stable isotope facility of the Paul Scherer Institute, Villigen, Switzerland. The $\delta^{13} \mathrm{C}$ was determined by combustion under excess $\mathrm{O}$ at a reactor temperature of $1,020^{\circ} \mathrm{C}$, whilst samples for $\delta^{18} \mathrm{O}$ measurement were pyrolysed to $\mathrm{CO}$ at $1,080^{\circ} \mathrm{C}$ (Saurer et al. 1998), both in continuous flow mode. This guarantees a high sample throughput rate with good precision for $\delta^{13} \mathrm{C} \quad(\sigma \pm 0.1 \%)$ and $\delta^{18} \mathrm{O}$ $(\sigma \pm 0.2 \%)$. The isotopic values were expressed in the $\delta$ notation relative to the international standards:

$\delta_{\text {sample }}=\left(R_{\text {sample }} / R_{\text {standard }}-1\right) \times 1000$,

where $R_{\text {sample }}$ is the molar fraction of ${ }^{13} \mathrm{C} /{ }^{12} \mathrm{C}$, or ${ }^{18} \mathrm{O} /{ }^{16} \mathrm{O}$ ratio of the sample and $R_{\text {standard }}$, of the standards Vienna Pee Dee belemnite for $\mathrm{C}$ and Vienna standard mean ocean water for $\mathrm{O}$.

Fossil fuel and "pre-industrial" correction for $\delta^{13} \mathrm{C}$

Correction of tree-ring $\delta^{13} \mathrm{C}$ is necessary because the combustion of fossil fuels and biomass and land-use changes have resulted in a decrease in $\delta^{13} \mathrm{C}$ of the atmospheric $\mathrm{CO}_{2}$ over the last 150 years. Changes in the isotopic ratio of atmospheric $\mathrm{CO}_{2}$ are directly reflected in the isotopic ratios of the products of photosynthesis. Calculating the differences for each year to the pre-industrial value (1850) for $\delta^{13} \mathrm{C}$ of atmospheric $\mathrm{CO}_{2}$ obtained from ice cores and direct atmospheric measurements at the Mauna Loa Observatory, Hawaii (Francey et al. 1999; http://www.esrl.noaa.gov/gmd/ccgg/globalview/co2c13/ co2c13_intro.html) we subtracted these differences from the raw isotope series for $\mathrm{C}$ for each year. Because isotope fractionation is additive, this completely removes the trend due to decreasing atmospheric $\delta^{13} \mathrm{C}$ from fossil fuel emissions and land-use changes.

After this correction, both wood and cellulose $\delta^{13} \mathrm{C}$ series still show a steep decline after 1960 that cannot be explained by any similar inflection in climate variables that might control fractionation. McCarroll et al. (2009) have argued that this is typical for the behavior of tree-ring $\delta^{13} \mathrm{C}$ series at many sites and that it represents a change in the response of trees to the increased availability of $\mathrm{CO}_{2}$. As the amount of $\mathrm{CO}_{2}$ in the air $\left(c_{\mathrm{a}}\right)$ has increased, trees have responded in an active way by increasing their water-use efficiency so that the ratio of $c_{\mathrm{i}}$ to $c_{\mathrm{a}}$ has remained constant. Since $\delta^{13} \mathrm{C}$ values are a function of the ratio $c_{\mathrm{i}} / c_{\mathrm{a}}$ they have also remained stable over the industrial period (Saurer et al. 1997a, b). In recent decades, however, many trees seem to have reached the limits of this plasticity in response and they no longer maintain a constant $c_{\mathrm{i}} / c_{\mathrm{a}}$ ratio, so that the $c_{\mathrm{i}}$ has increased, leading to a decline in $\delta^{13} \mathrm{C}$.

A "pre-industrial" (pin) correction taking account of this change in behavior has been proposed by McCarroll 
et al. (2009). It is a constrained non-linear de-trending of the $\delta^{13} \mathrm{C}$ series after 1850 and the constraints are based on the likely physiological response of trees to increased $\mathrm{CO}_{2}$. The first constraint is that a unit increase in the $c_{\mathrm{a}}$ cannot directly cause more than the same unit increase in $c_{\mathrm{i}}$, and the second constraint is that increases in water-use efficiency are limited to maintaining a constant $c_{\mathrm{i}} / c_{\mathrm{a}}$ ratio. The extent of the correction depends on the difference between an active response to increased $\mathrm{CO}_{2}$ (maintaining constant $c_{\mathrm{i}} / c_{\mathrm{a}}$ ) and a passive response (allowing $c_{\mathrm{i}}$ to increase in parallel with $c_{\mathrm{a}}$, so that $c_{\mathrm{a}}-c_{\mathrm{i}}$, which represents effectively water-use efficiency, remains constant). In the early industrial period, when atmospheric $\mathrm{CO}_{2}$ was increasing very slowly, it can only directly explain a small decline in tree-ring $\delta^{13} \mathrm{C}$, so any steeper decline is not removed. In more recent decades, when $\mathrm{CO}_{2}$ increased rapidly, it can account directly for a more rapid rise in $c_{\mathrm{i}}$ and so a steeper decline in $\delta^{13} \mathrm{C}$ can be removed.

When the pin correction of McCarroll et al. (2009) is applied to the data herein it has no effect until about 1960 and after that it removes the decline in $\delta{ }^{13} \mathrm{C}$ in both the whole wood and cellulose series completely. This is because prior to 1960 the isotope series are rising, which reflects an increase in water-use efficiency beyond that required to maintain a constant ratio $c_{\mathrm{i}} / c_{\mathrm{a}}$. This implies not only an active response to the rise in atmospheric $\mathrm{CO}_{2}$, but an additional environmental stress causing the trees to restrict moisture loss. The steep decline in both $\delta^{13} \mathrm{C}$ series after 1960 probably represents a change from an active to a more passive response and all of the decline could, in theory, be explained by an inability to respond to the increasingly rapid rate of increase in atmospheric $\mathrm{CO}_{2}$. In the discussion below the first correction of $\delta^{13} \mathrm{C}$ of atmospheric $\mathrm{CO}_{2}$ will be termed " $\delta{ }^{13} \mathrm{C}$ " and the second (pin) correction (McCarroll et al. 2009) " $\delta{ }^{13} \mathrm{C}^{*}$.

\section{Relation to climate}

To analyze the influence of climate on tree-ring formation, statistical analyses were performed with monthly temperature and precipitation data from the nearest meteorological station at Tura (30 km south of the study site). Pearson correlation coefficients were calculated between tree-ring width and isotope chronologies and meteorological measurements for the period where data were available (19292005). To investigate the stability of climatic signals over time, the analyzed period was divided into two periods of equal length (1929-1967 and 1967-2005). The vapor pressure deficit (VPD) was calculated for 1958-2006 using daily Tura weather station data assuming that $T_{\text {dew }}=$ $a+b T_{\min }$, (where $a$ and $b$ were calculated using the available daily data for relative humidity). $T_{\text {dew }}$ is the dew point temperature and $T_{\min }$ the minimum air temperature (Murray 1967$)$.

\section{Results}

Tree-ring width, stable isotopes, climatic parameters and their trends

The constructed larch tree-ring width index chronology (TRW) covers the period 1751-2006 (Fig. 2). The mean tree-ring width is $0.38 \mathrm{~mm}$ and the mean inter-series correlation is 0.59 . The EPS value is above the critical 0.85 level (EPS $=0.95$ ) and indicates a high degree of common variability between individual trees for the whole analyzed period. The TRW is characterized by a strong increase during 1864-1900. In the period 1900-1970, TRW decreases, while after the 1970s, the TRW again shows a slightly increasing trend (Fig. 2).

The stable isotope chronologies for $\delta^{13} \mathrm{C}$ and $\delta^{18} \mathrm{O}$ of whole wood and cellulose were determined for the period 1864-2006 (Fig. 3a, b). The $\delta^{13} \mathrm{C}$ series of both materials (Fig. 3a) steadily increase from 1864 to 1960, decrease afterwards when the $\delta^{13} \mathrm{C}$ correction is used, but still increased when the $\delta^{13} \mathrm{C}^{*}$ correction was applied (Fig. 3). Before $1960, \delta^{13} \mathrm{C}$ and $\delta^{13} \mathrm{C}^{*}$ corrections show similar results.

The mean $\delta^{18} \mathrm{O}$ values in cellulose decrease from 1864 to about 1960. Afterwards no clear trend can be identified (Fig. 3b). In contrast, the $\delta^{18} \mathrm{O}$ values of whole wood show a decreasing trend for the entire period (1864-2006). Wood and cellulose isotope values in general show similar variations, with a correlation coefficient $r=0.75(P<0.05)$ for $\mathrm{C}$ and $r=0.61(P<0.05)$ for $\mathrm{O}$ isotopes (1864-2006).

We observed a negative correlation between TRW and $\delta^{13} \mathrm{C}^{*}$ of wood $(r=-0.20, P<0.05)$ and cellulose

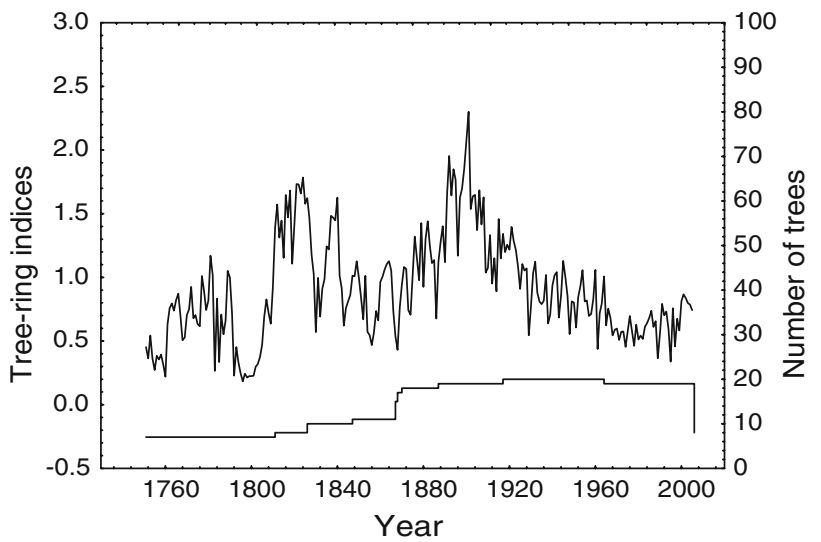

Fig. 2 Tree-ring width standardized chronology and tree replications are presented for the period 1751-2006 



Fig. 3 a Stable $\mathrm{C}$ isotope ratio $\left(\delta^{13} \mathrm{C}\right)$ and "pre-industrial" (pin) correction of $\delta^{13} \mathrm{C}\left(\delta^{13} \mathrm{C}^{*}\right)$ of wood (open circle, thin line) and cellulose (closed circle, bold line) and their trends in comparison for the period $1864-2005 . \delta^{13} \mathrm{C}^{*}$ is according to McCarroll et al. (2009) and the $\delta^{13} \mathrm{C}$ is a correction according to $\delta^{13} \mathrm{C}$ atmospheric $\mathrm{CO}_{2}$ (Francey et al. 1999). b Stable O isotope ratios $\left(\delta^{18} \mathrm{O}\right)$ of whole wood (open circle) and cellulose (closed circle) and their trends for the period 1864-2005. c July air temperature (open circle) and precipitation (triangle) and their trends for the period 1929-2005

$(r=-0.36, P<0.05)$ but a positive correlation with $\delta^{18} \mathrm{O}$ of whole wood $(r=0.26, P<0.05)$ and cellulose $(r=0.39, P<0.05)$ for $1864-2006$. No significant correlation between TRW and $\delta^{13} \mathrm{C}$ of cellulose was found.

The climate data show a slightly decreasing trend for July precipitation and an increasing trend for July air temperature during 1929-2005 (Fig. 3c). Monthly average temperatures and precipitation for each month were separated into two equal periods, 1929-1967 and 1967-2005, for a detailed climatological analysis. The average July precipitation decreased from $66.24 \mathrm{~mm}$ between 1929 and 1967 to $54.96 \mathrm{~mm}$ for $1967-2005$, whereas the annual amount of precipitation increased from 304.49 to $308.83 \mathrm{~mm}$, mainly due to an increase in winter precipitation (January, February). The average July temperature increased from $16.3^{\circ} \mathrm{C}$ between 1929 and 1967 to $16.9^{\circ} \mathrm{C}$ between 1967 and 2005, and the annual temperature increased by $0.2^{\circ} \mathrm{C}$.

Relationships between $\mathrm{C}$ and $\mathrm{O}$ isotopic signals

Running correlations between $\delta^{13} \mathrm{C}$ and $\delta^{18} \mathrm{O}$ of cellulose were calculated for the period 1929-2005 using a 20-year window (Fig. 4). Furthermore, regression coefficients between $\delta^{13} \mathrm{C}$ and $\delta^{18} \mathrm{O}$ of cellulose were calculated for the split periods 1929-1967 and 1967-2005. We observed that the relationship between the two isotopes was not constant over time. While we found a negative regression between $\delta^{13} \mathrm{C}$ and $\delta^{18} \mathrm{O}$ of cellulose $(r=-0.55 ; P<0.05)$ for 1929-1967, this regression became significantly positive from 1960 onwards $(r=0.38 ; P<0.05)$. No correlation between $\delta^{13} \mathrm{C}$ and $\delta^{18} \mathrm{O}$ of whole wood was found for 1929-1967, while for 1967-2005 a positive correlation (up to $r=0.37 ; P<0.05$ ) was observed.

Climatic analysis

Correlation coefficients between TRW, isotope values and Tura weather station data were calculated for the period when climate data are available (1929-2005). For a more detailed dendroclimatic analysis, we separated this period



Fig. 4 Running correlation coefficients between $\delta^{13} \mathrm{C}$ and $\delta^{18} \mathrm{O}$ of cellulose for the period 1929-2005 calculated with a 20-year window. The vertical line indicates the point where the correlation between $\delta^{13} \mathrm{C}$ and $\delta^{18} \mathrm{O}$ began to increase (after the 1960s) and where the correlation between the two isotopes became positive. For abbreviations, see Fig. 3 
into two equal parts as discussed above (1929-1967 and 1967-2005) because different tendencies in the radial tree growth were observed before (negative trend) and after (positive trend) 1967 (Fig. 2). We found significant, but not very strong positive correlations between TRW and temperatures of May and June as well as July precipitation for 1929-2005 (Fig. 5). The $\delta^{13} \mathrm{C}$ and $\delta^{13} \mathrm{C}^{*}$ values of cellulose show a positive correlation with July air temperature and a negative correlation with July precipitation (Fig. 5). Similarly, positive correlations were found between $\delta^{13} \mathrm{C}^{*}$ of whole wood and temperature but for June $(r=0.29$; $P<0.05)$ instead of July, and a negative correlation with precipitation of July $(r=-0.37 ; P<0.05)$ for $1929-$ 2005. When considering only the most recent period (1967-2005), we observed a negative correlation between $\delta^{13} \mathrm{C}^{*}$ and the annual amount of precipitation $(r=-0.26$ and $r=-0.35 ; P<0.05)$ for whole wood and cellulose, respectively.

Regarding the $\delta^{18} \mathrm{O}$ of cellulose, we did not find any significant correlation with monthly values of temperature and precipitation, but with annual temperature and precipitation for both periods 1929-2005 and 1929-1967 ( $r=0.24$ and $r=0.40 ; P<0.05$, respectively). In contrast, $\delta^{18} \mathrm{O}$ of wood was not correlated with annual temperature and precipitation but a negative correlation with the average minimum temperature of February $(r=$ $-0.44 ; P<0.05)$ for the period 1967-2005 was observed. Finally, we found positive correlations between $\delta^{13} \mathrm{C}^{*}$ of whole wood and VPD for June $(r=0.42 ; P<0.05)$ and between VPD of July and $\delta^{13} \mathrm{C}^{*}(r=0.51, P<0.05)$ and $\delta^{18} \mathrm{O}(r=041, P<0.05)$ of cellulose.

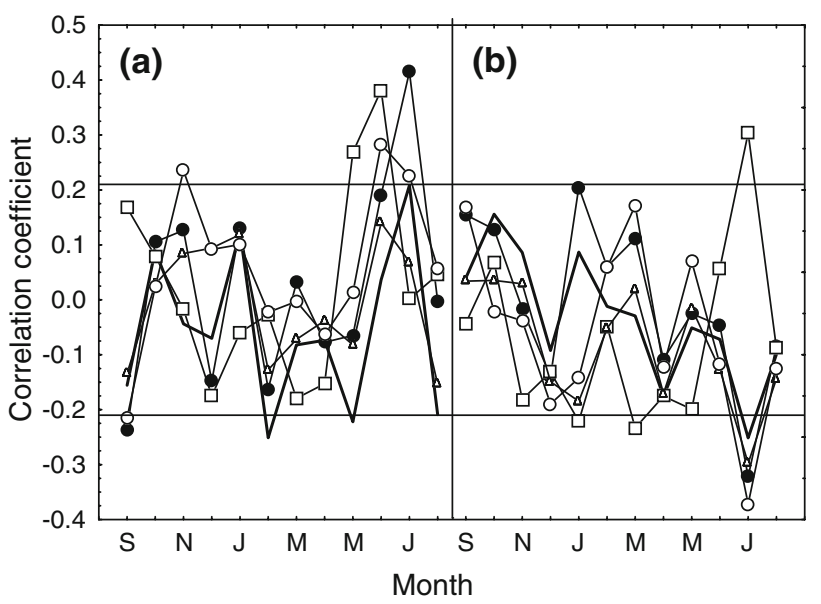

Fig. 5 Correlation coefficients between temperature (a) and precipitation (b) from September of the previous year to August of the current year and tree-ring width index chronology (open square), $\delta^{13} \mathrm{C}^{*}$ of wood and cellulose (open and closed circles) and $\delta^{13} \mathrm{C}$ of wood and cellulose (thin and bold lines), respectively. The horizontal lines show the significance level $(P<0.05)$. For abbreviations, see Fig. 3

\section{Discussion}

The TRW developed for the Tura region has a pattern common for chronologies of central Siberia, showing periods of relatively low growth alternating with abrupt growth increases (Fig. 2). Such a pattern is mostly explained by post-fire tree-ring growth after low-intensity forest fires (Kharuk et al. 2008). Early studies showed that the mean interval between fires is 80-200 years depending on exposure and vegetation (Arbatskaya 1998; Kharuk et al. 2008), which is in the range the observed frequency in our study for intervals between strong growth increases. Forest fires destroy the moss-lichen layer, which provides thermal insulation, and can remove up to $70 \%$ of the annual ecosystem production (Abaimov et al. 1997; Knorre et al. 2006; Prokushkin et al. 2006). The enhanced radiation on the soil leads to permafrost thawing and to an increase in the active soil layer. The melting permafrost water is highly depleted in ${ }^{18} \mathrm{O}$ and could therefore result in decreasing isotopic trends in tree rings (Fig. 3b). The melting permafrost water, however, can not be conserved for a long time and is lost due to evaporation and run-off to streams and rivers, leading to drought in the active layer and decreasing tree growth as was observed at our study site for the period after 1900 (Fig. 2). In this case the rain water, which is isotopically heavier than melting permafrost water, may play a key role as a source of water for the trees. The exact position of the permafrost is critical for tree growth and may be detrimental if either too low or too high.

After a fire several years are needed for recovery (Abaimov et al. 1997). As a consequence the permafrost layer rises again and reduces the growth and functionality of the tree root systems (Alvarez and Körner 2007). The permafrost has an important role as a direct water source in summer drought because it buffers water availability to plants. Sugimoto et al. (2002) reported that the pine forest in eastern Siberia might be seriously damaged by a water deficit in summer droughts if the permafrost disappeared. On the other hand, when the permafrost table rises, root growth decreases. It was found that the rate of permafrost rise is inversely proportional to the growth rate of the mosses (Knorre et al. 2006).

The tree-ring indices curve shows an abrupt decrease in radial tree growth for the periods 1790-1810 and 18401849 , and then a rapid increase up to 1901 followed by a continuous decrease (Fig. 2). We assume that the periods with reduced tree-ring growth were caused by shallow permafrost resulting in low water and nutrient availability. Regarding the declining growth trend over the 20th century, our results are in agreement with Barber et al. (2000, 2004), who reported a decrease in radial tree growth with increasing temperature as a consequence of drought stress. 
During drought stress stomata close in order to prevent water loss. A slowly increasing $c_{\mathrm{a}}$ and $c_{\mathrm{i}}$ might further reduce the stomatal conductance while maintaining photosynthesis and tree radial growth at the same level towards the end of the 21 st century. A reduced stomatal conductance is reflected in increased $\delta^{18} \mathrm{O}$ values, because the leaf water enrichment in $\mathrm{H}_{2}^{18} \mathrm{O}$ is reduced to a lesser degree by the convective flow of depleted source water (via the xylem) than at higher transpiration rates (Péclet effect; Farquhar and Lloyd 1993). In fact, we observed a slight increase in $\delta^{18} \mathrm{O}$ of wood and cellulose for the period 1967-2005 in comparison with 1929-1967 that indicates a drought (Fig. 3b).

The overall trends over the 20th century show a decrease in $\delta^{18} \mathrm{O}$, tree-ring width, precipitation and an increase of July air temperature, July VPD and $\delta^{13} \mathrm{C}$ (Fig. 3). After separating the climatic data (1929-2005) into two equal parts, however, we observed a slight decrease for the $\delta^{18} \mathrm{O}$ in cellulose between 1929 and 1967 , while the $\delta^{13} \mathrm{C}, \delta^{13} \mathrm{C}^{*}$, temperature and precipitation of July were relatively constant or slightly increased. After 1960 s the $\delta^{13} \mathrm{C}$ and $\delta^{13} \mathrm{C}^{*}$ chronologies diverge, suggesting that this is the period where increased atmospheric $\mathrm{CO}_{2}$ becomes most effective. According to the theory outlined in the section "Fossil fuel and pre-industrial correction for $\delta^{13} \mathrm{C}$ ", this indicates that the trees are no longer able to maintain a constant $c_{\mathrm{i}} / c_{\mathrm{a}}$, but $c_{\mathrm{i}}$ is increasing resulting in lower $\delta^{13} \mathrm{C}$ values. This is clearly a non-climatic, physiological effect that will hamper correlation analysis with climate for the last few decades. The $\delta^{18} \mathrm{O}$ of cellulose was relatively constant, as were tree-ring width and the $\delta^{13} \mathrm{C}^{*}$, whereas the $\delta^{13} \mathrm{C}$ clearly decreased.

Declining tree-ring $\delta^{13} \mathrm{C}$ trends in recent decades were observed at other locations in interior Alaska (Barber et al. 2004) and northern Finland (Gagen et al. 2007). In Finland (Laanila) a divergence between $\delta^{13} \mathrm{C}$ and $\delta^{13} \mathrm{C}^{*}$ of cellulose has been observed since 1880 but in central Siberia (Tura) it was not observed before 1960. Such a variation in the response of trees from these different regions could be due to differences in climatic conditions, differences in microbial activity and nutrient availability in the soil or different responses of trees to elevated $\mathrm{CO}_{2}$ in the atmosphere. Such differences in the timing and magnitude of responses are predicted by McCarroll et al. (2009), who argue that there is no reason to suggest that all trees should respond in the same way. A previous stable isotope study for Siberian Scots pine in Turuchansk $\left(66^{\circ} \mathrm{N}\right)$ showed a declining trend in $\Delta^{13} \mathrm{C}_{\mathrm{c}}$ for the second half of the 20th century. Arneth et al. (2002) explained the trend by tree responses to increasing atmospheric $\mathrm{CO}_{2}$ concentration and increasing water-use efficiency due to increasing soil water deficit and declining air humidity.

Climatological analysis showed positive correlations between $\mathrm{C}$ isotope chronologies and temperatures of June and July in whole wood and cellulose. This is expected because June and July are the warmest months and these relationships indicate an increase in photosynthetic capacity and VPD. The warm and dry conditions cause stomatal closure and lower the isotopic fractionation, leading to less negative $\delta^{13} \mathrm{C}$ values. The VPD is related to a reduction in stomatal conductance and a further increase in $\delta^{18} \mathrm{O}$ enrichment of leaf water. Even during the warmest month of July, the soil water is still frozen at a depth of $20-30 \mathrm{~cm}$. The melting water is still cold and cannot be used by roots at the low soil temperature (Kramer and Boyer 1995). Thus the accessibility of water for trees is limited, which can lead to drought.

In contrast, the monthly temperatures were not significantly represented in the $\delta^{18} \mathrm{O}$ values. The positive correlations with annual temperature, VPD of July and the negative correlation with annual precipitation were observed only for $\delta^{18} \mathrm{O}$. In general we observed lower statistical relationships compared to other studies (Gagen et al. 2007) which could be due to the complex site conditions with frozen soil.

Numerous papers have reported similarities between whole wood and cellulose for $\delta^{13} \mathrm{C}$ (Leavitt and Long 1991; Borella et al. 1998), suggesting that similar climatic signals are contained in both materials. However, our analysis of $\delta^{13} \mathrm{C}$ in whole wood reflects the June temperature signal and $\delta^{18} \mathrm{O}$ of whole wood correlates with monthly minimum temperatures, while none of these signals were found in cellulose (Fig. 5). One reason for the presence of different signals in whole wood and cellulose could be the direct link between chemical composition of needles and isotopic ratios in whole wood (Loader et al. 2003). In contrast, initial cellulose synthesis begins earlier in the season with a mixture of predominantly stored (old) and freshly assimilated carbohydrates (Helle and Schleser 2004). Another reason could be that the changes of the environmental conditions alter the ratio of the wood compounds, as was found for plants exposed to elevated $\mathrm{CO}_{2}$ (Körner 2000). In our previous study from a more northern and more eastern Siberian site, we suggested analyzing both whole wood and cellulose if sufficient material is available because they contain different climatic signals (Sidorova et al. 2008), and that conclusion seems to be supported by the data presented here.

The application of the $\delta^{13} \mathrm{C}^{*}$ correction removes the strong decreasing trend in tree-ring $\delta^{13} \mathrm{C}$ by taking the increasing $c_{\mathrm{a}}$ into account. This correction was developed specifically for removing changes in the physiological response of trees in order to clarify the influence of climate and thus use stable $\mathrm{C}$ isotopes in tree rings to reconstruct the climate of the past. Therefore, the $\delta^{13} \mathrm{C}^{*}$ values cannot be used for the analysis of physiological responses to elevated $\mathrm{CO}_{2}$; they can, however, indicate when the impact of rising $\mathrm{CO}_{2}$ becomes physiologically relevant. 
A pronounced negative correlation between $\mathrm{C}$ and $\mathrm{O}$ isotopes for 1929-1967 was observed (Fig. 4) and this opposite behavior of the two isotopes could be explained by a relatively constant stomatal conductance and decreasing photosynthetic capacity according to the model by Scheidegger et al. (2000). This period is characterized by slightly increasing July precipitation. Under such conditions the plant water loss is low and the stomata can be open, which is reflected in a lower enrichment of $\delta^{18} \mathrm{O}$ in needle water. The application of the concept of Scheidegger et al. (2000) to the isotope data therefore suggests a decrease in photosynthesis, which is in line with the observed declining tree-ring indices (Fig. 2).

In contrast, the period 1967-2005 is characterized by an increase in the annual amount of precipitation, mainly January and February. A lot of precipitation falling in winter can lead to the delay of snow melt (because the spring temperature did not change significantly for the last 50 years) and result in limited source water at the beginning of the period of vegetative growth and a decrease in wood production (Kirdyanov et al. 2003). Accordingly, we observed a change from a negative to a positive correlation between $\mathrm{C}$ and $\mathrm{O}$ isotope chronologies for this latter period. An increase in $\delta^{13} \mathrm{C}^{*}$ indicates a decreasing $c_{\mathrm{i}}$. This is either due to a reduced stomatal conductance at a constant photosynthetic rate or a constant stomatal conductance under an increased $\mathrm{CO}_{2}$ uptake. The observed slight rise in $\delta^{18} \mathrm{O}$, however, indicates a reduction in stomatal conductance. Thus the relationship of the $\mathrm{C}$ and $\mathrm{O}$ isotope ratios suggests a shift towards a drier climate during the growth period (Scheidegger et al. 2000; Yakir and Sternberg 2000). Obviously the occurrence of drought depends strongly on local soil conditions and a generalization based on the results from one site applied to larger areas is therefore difficult.

The stagnation in radial growth during the last 30 years, similar to that observed for many sites in high latitudes of the northern hemisphere (Briffa et al. 1998; Barber et al. 2000), and the strong impact of the correction for increased $\mathrm{CO}_{2}$ at this time suggests that the trees there cannot utilize the increasing $\mathrm{CO}_{2}$ concentration any further under the given environmental conditions. The beginning of an increasing drought and the limited access to nutrients in the permafrost region strongly suggest $\mathrm{CO}_{2}$ saturation of these trees. As the photosynthetic capacity can no longer be enhanced the $c_{\mathrm{i}}$ will increase along with the $c_{\mathrm{a}}$. Thus the ${ }^{13} \mathrm{CO}_{2}$ discrimination will increase with increasing $\mathrm{CO}_{2}$ concentration resulting in a continuous decrease in $\delta^{13} \mathrm{C}$, in spite of a reduction in stomatal conductance, which is documented with an increase in $\delta^{18} \mathrm{O}$. Finally we conclude that these unique data represent the response of larch trees to a slowly developing water shortage in the most recent half century, even in this cold permafrost region.
Acknowledgments This study was supported by the Swiss National Science Foundation (SNF 200021_121838/1, PIOI2-119259), the Joint Research Project SCOPES (no. IB73A0-111134), and the Russian Foundation for Basic Research (RFBR nos. 06-05-64095-a, 07-04-96819 r_enisey, 07-04-00293a, 09-05-98015_r_sibir_a). This work was conducted in collaboration with the European Union-funded Millennium Project (017008). Special thanks to Prof. Danny McCarroll from Swansea University, UK for useful discussion and valuable comments on the early stage of this manuscript. We would like to thank the editor-in-chief, Christian Körner, the handling editor, Dan Yakir, and the two anonymous reviewers for their helpful comments.

\section{References}

Abaimov AP, Bondarev AI, Zyryanova OA, Shitova SA (1997) Polar forests of Krasnoyarsk region. Novosibirsk, Nauka, p 208

Alvarez UP, Körner C (2007) Low temperature limits of root growth in deciduous and evergreen temperature tree species. Funct Ecol $21: 211-218$

Arbatskaya MK (1998) Long term variability of climate, tree growth and fire frequencies in taiga of Middle Siberia (in Russian). $\mathrm{PhD}$ thesis, Institute of Forest, Krasnoyarsk, Russia

Arneth A, Lloyd J, Santruckova H, Bird M, Grigoryev S, Kalaschnikov YN, Gleixner G, Schulze ED (2002) Response of central Siberian Scots pine to soil water deficit and long-term trends in atmospheric $\mathrm{CO}_{2}$ concentration. Global Biogeochem Cycles 16 . 1.10.1029/2000GB001374

Barber VA, Juday GP, Finney B (2000) Reduced growth of Alaskan white spruce in the twentieth century from temperature-induced drought stress. Nature 405:668-673

Barber VA, Juday GP, Finney BP, Wilmking M (2004) Reconstruction of summer temperature in interior Alaska from tree ring proxies: evidence for changing synoptic climate regimes. Clim Change 63:91-120

Barbour MM, Andrei TJ, Farquhar GD (2001) Correlation between oxygen isotope ratios of wood constituents of Quercus and Pinus samples from around the world. Aust J Plant Physiol 28:335-348

Borella S, Leuenberger M, Saurer M (1998) Reducing uncertainties in $\delta^{13} \mathrm{C}$ analysis of tree rings: pooling, milling, and cellulose extraction. J Geophys Res 103, NO.D.16:19519-19526

Briffa KR (2000) Annual climate variability in the Holocene: interpreting the message of ancient trees. Quat Sci Rev 19:87105

Briffa K, Schweingruber F, Jones P, Osborn T (1998) Reduced sensitivity of recent tree growth to temperature at high northern latitudes. Nature 391:678-682

Cernusak LA, Pate JS, Farquhar GD (2003) Diurnal variation in the stable isotope composition of water and dry matter in fruiting Lupinus angustifolius under field conditions. Plant Cell Environ 25:893-907

Cook ER, Kairiukstis LA (eds) (1990) Methods of dendrochronology. Applications in the environmental sciences. Kluwer, Dordrecht, p 394

Cook ER, Krusic PJ (2008) A tree-ring standardization program based on detrending and autoregressive time series modeling, with interactive graphics (ARSTAN)

Craig H (1961) Isotopic variations in meteoric waters. Science 133:1702-1703

D'Arrigo R, Kaufmann RK, Davi N, Jacoby GC, Laskowski C, Myneni RB, Cherubini P (2004) Thresholds for warming induced growth decline at elevational tree line in the Yukon territory, Canada. Glob Biogeochem Cycles 18. doi:10.1029/ 2004GB002249 
Dansgaard W (1964) Stable isotopes in precipitation. Tellus B Chem Phys Meteorol 16:436-468

Delisle G (2007) Near-surface permafrost degradation: how severe during the 21st century? Geophys Res Lett 34:L09503. doi: 1029/2007GL029323

Drake BG, GonzalezMeler MA, Long SP (1997) More efficient plants: a consequence of rising atmospheric $\mathrm{CO}_{2}$ ? Annu Rev Plant Physiol Plant Mol Biol 48:609-639

Duquensnay A, Breda N, Stievenard M, Dupouey JL (1998) Changes of tree-ring $\delta^{13} \mathrm{C}$ and water-use efficiency of beech (Fagus sylvatica L.) in north-eastern France during the past century. Plant Cell Environ 21:565-572

Farquhar GD, Lloyd J (1993) Carbon and oxygen isotope effects in the exchange of carbon dioxide between plants and the atmosphere. In: Ehleringer JR, Hall AE, Farquhar GD (eds) Stable isotope and plant carbon/water relations. Academic Press, San Diego, pp 47-70

Farquhar GD, Ehleringer JR, Hubick KT (1989) Carbon isotope discrimination and photosynthesis. Annu Rev Plant Physiol Plant Mol Biol 40:503-537

Francey RJ, Allison CE, Etheridge DM (1999) A 1000-year high precision record of $\delta^{13} \mathrm{C}$ in atmospheric $\mathrm{CO}_{2}$. Tellus B Chem Phys Meteorol 51:170-193

Gagen MH, McCarroll D, Edouard J-L (2004) Latewood width, maximum density and stable carbon isotope ratios of pine as climate indicators in a dry, subalpine environment. Arct Antarct Alp Res 36:166-171

Gagen MH, McCarroll D, Edouard J-L (2006) Combining ring width, density and stable carbon isotope proxies to enhance the climate signal in tree-rings: an example from the southern French Alps. Clim Change 78:363-379

Gagen MH, McCarrol D, Loader NJ, Robertson I, Jalkanen R, Anchukaitis KJ (2007) Exorcising the 'segment length curse' summer temperature reconstruction since AD 1640 using non de-trend stable carbon isotope ratios from line trees in northern Finland. Holocene 17:433-444

Gagen MH, McCarrol D, Robertson I, Loader NJ, Jalkanen R (2008) Do tree ring $\delta^{13} \mathrm{C}$ series from Pinus sylvestris in northern Fennoscandia contain long-term non-climatic trends? Chem Geol 252:42-51

Graumlich LJ (1991) Subalpine tree growth, climate, and increasing $\mathrm{CO}_{2}$ : an assessment of recent growth trends. Ecology 72:1-11

Helle G, Schleser GH (2004) Beyond $\mathrm{CO}_{2}$-fixation by Rubisco-an interpretation of ${ }^{13} \mathrm{C} /{ }^{12} \mathrm{C}$ variations in tree rings from novel intraseasonal studies on broad-leaf trees. Plant Cell Environ 27:367380

IPCC (2001) Climate change 2001: the scientific basis. In: Houghton JT, et al. (eds) Contribution of Working Group I to the 3rd assessment report of the Intergovernmental Panel on Climate Change. Cambridge University Press, USA

IPCC (2007) 4th assessment report, chapter 6. Intergovernmental Panel on Climate Change, pp 434-497

Kagawa A, Naito D, Sugimoto A, Maximov TC (2003) Effects of spatial variability in soil moisture on widths and $\delta^{13} \mathrm{C}$ values of eastern Siberian tree rings. J Geophys Res 108:D164500. doi: 10.1029/2002JD003019

Kajimoto T, Matsuura Y, Osawa A, Prokushkin AS, Sofronov MA, Abaimov AP (2003) Root system development of Larix gmelinii trees affected by micro-scale conditions of permafrost soils in central Siberia. Plant Soil 255:281-292

Keeling CD, Chin JFS, Whorf TP (1996) Increased activity of northern vegetation inferred from atmospheric $\mathrm{CO}_{2}$ measurements. Nature 382:146-149

Kharuk VI, Ranson KJ, Dvinskaya ML (2008) Wildfires dynamic in the larch dominance zone. Geophys Res Lett 35:L01402. doi: 10.1029/2007GL032291
Kirdyanov AV, Hughes M, Vaganov EA, Schweingruber F, Silkin P (2003) The importance of early summer temperature and date of snow melt for tree growth in the Siberian Subarctic. Trees 17:61-69

Kirdyanov AV, Treydte KS, Nikolaev A, Helle G, Schleser GH (2008) Climatic signals in tree ring width, density and $\delta^{13} \mathrm{C}$ from larches in Eastern Siberia (Russia). Chem Geol 252:31-41

Knorre AA, Kirdyanov AA, Vaganov EA (2006) Climatically induced interannual variability in aboveground production in forest-tundra and northern taiga of central Siberia. Oecologia 147:86-95. doi:10.1007/s00442-005-0248-4

Körner C (2000) Biosphere responses to $\mathrm{CO}_{2}$ enrichment. Ecol Appl 10(6):1590-1619

Kramer PJ, Boyer JS (1995) Water relations of plants and soils. Academic Press, New York, pp 167-199

Leavitt SW, Long A (1991) Seasonal stable-carbon isotope variability in tree rings: possible paleoenvironmental signals. Chem Geol (Isot Geosci Sect) 87:59-70

Leavitt SW, Chase TN, Rajagopalan B, Lee E, Lawrence PJ (2008) Southwestern US tree-ring carbon isotope indices as a possible proxy for reconstruction of greenness of vegetation. Geophys Res Lett 35:L12704. doi:10.1029/2008GL033894

Loader NJ, Robertson I, Barker AC, Switsur VR, Waterhouse JS (1997) Improved technique for the batch processing of small whole wood samples to alpha-cellulose. Chem Geol 136:313-317

Loader NJ, Robertson I, McCarroll D (2003) Comparison of stable carbon isotope ratios in the whole wood, cellulose and lignin of oak tree rings, Palaeogeography, Palaeoclimatology. Palaeoecology 196:395-407

McCarroll D, Loader NJ (2004) Stable isotopes in tree rings. Quat Sci Rev 23:771-801

McCarroll D, Pawellek F (2001) Stable carbon isotope ratios of Pinus sylvestris from northern Finland and the potential for extracting a climate signal from long Fennoscandian chronologies. Holocene 11:517-526

McCarroll D, Gagen MH, Loader NJ, Robertson I, Anchukaitis KJ, Los S, Young G, Jalkanen R, Kirchhefer A, Waterhouse JS (2009) Correction of tree ring stable carbon isotope chronologies for changes in the carbon dioxide content of the atmosphere. Geochim Cosmochim Acta. doi:10.1016/j.ca.2008.11.041

Murray FW (1967) On the computation of saturation vapor pressure. J Appl Meteorol 6:203-204

Myneni RB, Keeling CD, Tucker CJ, Asrar G, Namani RR (1997) Increased plant growth in the northern high latitudes from 19811991. Nature 386:698-702

Osterkamp TE, Romanovsky VE (1999) Evidence for warming and thawing of discontinuous permafrost in Alaska. Permafr Periglac Process 10(1): 17-37

Prokushkin AS, Knorre AA, Kirdyanov AV, Schulze ED (2006) Productivity of mosses and organic matter accumulation in the litter of sphagnum larch forest in the permafrost zone. Russ $\mathbf{J}$ Ecol 374:225-232. doi:10.1134/S1067413606040023

Rinn F (1996) TSAP, V. 3.6. Reference manual computer program for tree ring analysis and presentation. Heidelberg, p 263

Roden JS, Ehleringer JR (2000) Hydrogen and oxygen isotope ratios of leaf water and tree ring cellulose for field grown riparian trees. Oecologia 123:481-489

Saurer M, Siegwolf RTW (2007) Human impacts on tree ring growth reconstructed from stable isotopes. In: Dawson Todd E, Siegwolf RTW (eds) Stable isotopes as indicators of ecological change terrestrial ecology series. Elsevier, Amsterdam, pp 49-62

Saurer M, Borella S, Schweingruber F, Siegwolf R (1997a) Stable isotopes in tree rings of beech: climatic versus site-related influences. Trees 11:291-297

Saurer M, Aellen K, Siegwolf R (1997b) Correlating $\delta^{13} \mathrm{C}$ and $\delta^{18} \mathrm{O}$ in cellulose of trees. Plant Cell Environ 20:1543-1550 
Saurer M, Robertson I, Siegwolf R, Leuenberger M (1998) Oxygen isotope analysis of cellulose: an inter-laboratory comparison. Anal Chem 70(10):2074-2080

Saurer M, Schweingruber F, Vaganov EA, Schiyatov SG, Siegwolf R (2002) Spatial and temporal oxygen isotope trends at the northern tree-line in Eurasia. Geophys Res Lett 29(9): 10.1029/2001GL013739

Scheidegger Y, Saurer M, Bahn M, Siegwolf R (2000) Linking stable isotopes with stomatal conductance and photosynthetic capacity: a conceptual model. Oecologia 125:350-357

Schweingruber FH (1996) Tree rings and environment dendroecology. Paul Haupt Publ Bern, Stuttgart, p 609

Serreze MC, Dyurgerov M, Romanovsky V, Oechel WC, Zhang JT, Barry RG, Walsh JE, Chappin III, Osterkamp T (2000) Observational evidence of recent change in the northern highlatitude environment. Clim Change 46(1-2):159-207

Sidorova OV, Siegwolf RTW, Saurer M, Naurzbaev M, Vaganov EA (2008) Isotopic composition $\left(\delta^{13} \mathrm{C}, \delta^{18} \mathrm{O}\right)$ in wood and cellulose of Siberian larch trees for early Medieval and recent periods. J Geophys Res Biogeosci 113:G02019. doi:10.1029/ 2007JG000473

Sternberg L, Deniro MJ, Savidge R (1986) Oxygen isotope exchange between metabolites and water during biochemical reactions leading to cellulose synthesis. Plant Physiol 82:423-427
Sugimoto A, Yanagisawa N, Naito D, Fujita N, Maximov TC (2002) Importance of permafrost as a source of water for plants in east Siberian taiga. Ecol Res 17:493-503

Treydte K, Schleser GH, Schweingruber FH, Winiger M (2001) The climatic significance of $\delta^{13} \mathrm{C}$ in subalpine spruce (Loetschental, Swiss Alps). Tellus B Chem Phys Meteorol 53B:593-611

USDA (1998) Keys to soil taxonomy, 8th edn. USDA, Natural Resources Conservation Service, Washington DC

Vaganov EA, Shiyatov SG (1998) Dendrochronological study in Siberian climate. In: The problem of climate reconstruction and nature in the Holocene and Pleistocene. Novosibirsk, pp 56-63

Vaganov EA, Hughes MK, Kirdyanov AV, Schweingruber FH, Silkin PP (1999) Influence of snowfall and melt timing on tree growth in subarctic Eurasia. Nature 400:149-151

Wigley T, Briffa K, Jones P (1984) On the average value of correlated time series, with application in dendroclimatology and hydrometeorology. J Clim Appl Meteorol 23:201-213

Wilmking M, Juday GP (2005) Longitudinal variation of radial growth at Alaska's northern treeline-recent changes and possible scenarios for the 21st century. Glob Planet Change 47:282-300

Yakir DL, Sternberg L (2000) The use of stable isotopes to study ecosystem gas exchange. Oecologia 123:297-311 